\title{
Cuttlebone morphometrics and sex identification of Sepia bertheloti (d'Orbigny, 1835) from the central-east Atlantic
}

\author{
Airam Guerra-Marrero* (D, David Jiménez-Alvarado, Vicente Hernández-García, Leticia Curbelo-Muñoz \\ and José Juan Castro-Hernández
}

\begin{abstract}
Analysis of 322 cuttlebones of Sepia bertheloti caught in the waters of the Northwest Africa showed significant differences in growth between males and females. Morphometric analysis revealed a relatively different cuttlebone growth pattern between sexes, with males presenting faster growth in length to reach larger sizes and females displaying greater growth in width. This difference in cuttlebone growth is related to female gonadal development and the subsequent increase of the paleal cavity, providing more support and space to accommodate a higher number of oocytes.
\end{abstract}

Keywords: African cuttlefish, Sepia bertheloti, Cuttlebone, Fragmocone

\section{Introduction}

The use of morphometric analysis to define basic characters of growth or development of some structures in cephalopods has been applied from the first contributions of Hoyle [1]. These morphometric analyses, called "Traditional morphometry" [2], compare the linear dimensions of different parts of an organism to define statistical relationships with objectives, such as the taxonomic differentiation of species or intra-specific morphometric differences between sexes. These characteristics have been used for the Sepiidae family, mainly for taxonomic differentiation [3], as well as to analyse morphometric differences within the same species [4].

Within the cephalopods context, the Sepiidae family represents a special interest for studies of hard structures due to the presence of the cuttlebone [5]. The cuttlebone is a complex structure composed of calcium carbonate in its aragonite polymorph mixed with a small amount of organic matter and a complex of $\beta$-chitin and protein $[6$, 7] that provides internal skeletal support and buoyancy

\footnotetext{
*Correspondence: airamgmarrero@gmail.com
}

Instituto Universitario EcoAqua, University of Las Palmas de Gran Canaria,

Edf. Ciencias Básicas, Campus de Tafira, Las Palmas de Gran Canaria,

35017 Las Palmas, Spain to the individual [8]. The cuttlebone shows a structure finely laminated (lamellas). According to Bettencourt and Guerra [9] and Chung and Wang [10], the periodicity of lamellar deposition depends on a combination of physiological and environmental factors (i.e., water temperature).

Sepia bertheloti and Sepia hierredda are by-catch species in the bottom trawl fishery targeting Sepia officinalis along the coast of the western Sahara [11]; There are no separate statistics of catches/landings for both species because they are caught and marketed together, but S. bertheloti represents between 11 and $35 \%$ of catches reported for both by-catch species [12]. In addition, probably due to the low commercial interest for $S$. bertheloti, most knowledge on this species has been obtained from the analysis of stomach contents of their natural predators $[13,14]$ by exploratory fishing to assess the status of the resources $[15,16]$ or for analyses of metal concentrations [17].

In this context, any contribution to the biology and ecology of S. bertheloti would contribute to its conservation and fishery management. The morphologic study of the cuttlebone could provide useful information for the assessment and estimation of mortality, particularly when the individuals are broken and only the cuttlebone 


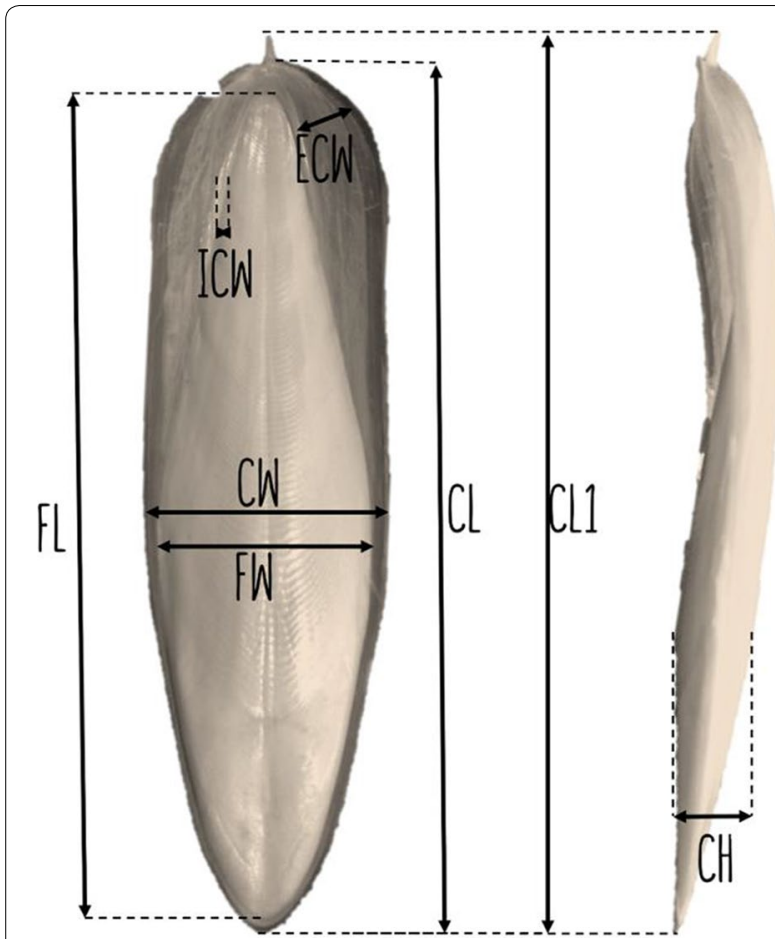

Fig. 1 Morphometric measurements of the cuttlebone of Sepia bertheloti: Cuttlebone Length (CL), total Cuttlebone Length (CL1), Cuttlebone Height $(\mathrm{CH})$, Cuttlebone Width (CW), Fragmocone Length (FL), Fragmocone Width (FW), Internal Cuttlebone Width (ICW) and External Cuttlebone Width (ECW) appear in the captures [4]. Almonacid-Rioseco [18] indicated that in the small-scale trap fishery off the Canary Islands, approximately $50 \%$ of S. officinalis caught were represented only by cuttlebones and obviously not reported in the landings. This characteristic makes it necessary to study these hard structures to estimate not only the actual catches by the different fishing gears but also the productivity of the area where the diverse fishing sectors operate.

In this context, the objective of this study was to describe the morphometric relationships of the cuttlebone of $S$. bertheloti and detect eventual differences between males and females caught in the northwest African waters.

\section{Material and methods}

A total of 322 individuals (247 males and 74 females) of $S$. bertheloti were obtained from commercial catches landed in the port of Tanger (Morocco) and by the bottom trawl fishery in the central-east Atlantic (CECAF area 34.1.11) from July to September 2018. All samples were immediately frozen after being caught. The specimens of $S$. bertheloti were identified following the key proposed by Nesis [19].

After defrosting, the Dorsal Mantle Length (DML), Total wet Weight (TW) and Gonad Weight (GW) were recorded for each specimen. Moreover, each cuttlebone was removed, weighted and measured according

Table 1 Parameters of the morphometric relationships established between the dorsal mantle length (DML) and cuttlebone measurements in male and female Sepia bertheloti

\begin{tabular}{|c|c|c|c|c|c|c|c|}
\hline Variable & Sex & $a$ & a standard error & b & b standard error & $\mathbf{R}$ & $F$ \\
\hline \multirow[t]{2}{*}{$\mathrm{FL}$} & $\mathrm{F}$ & 0.139 & 0.020 & 0.933 & 0.033 & 0.968 & 1778.5 \\
\hline & $M$ & 0.255 & 0.050 & 0.796 & 0.045 & 0.939 & 1315.1 \\
\hline \multirow[t]{2}{*}{ FW } & $F$ & 0.476 & 0.059 & 0.939 & 0.040 & 0.954 & 2538.1 \\
\hline & $M$ & 3.321 & 0.186 & 0.799 & 0.024 & 0.931 & 1063.3 \\
\hline \multirow[t]{2}{*}{$C W$} & $F$ & 0.211 & 0.036 & 1.147 & 0.054 & 0.946 & 2452.1 \\
\hline & $M$ & 3.814 & 0.179 & 0.794 & 0.020 & 0.949 & 1500.2 \\
\hline \multirow[t]{2}{*}{$\mathrm{ECW}$} & $\mathrm{F}$ & 0.941 & 0.126 & 1.094 & 0.067 & 0.913 & 1266.4 \\
\hline & $M$ & 0.402 & 0.280 & 1.182 & 0.030 & 0.951 & 1543.1 \\
\hline \multirow[t]{2}{*}{$C L$} & $\mathrm{~F}$ & 0.915 & 0.028 & 0.148 & 0.018 & 0.977 & 1056.9 \\
\hline & $M$ & 0.192 & 0.036 & 0.856 & 0.043 & 0.951 & 3398.6 \\
\hline \multirow[t]{2}{*}{ CL1 } & $F$ & 0.957 & 0.082 & 0.119 & 0.043 & 0.880 & 436.9 \\
\hline & $M$ & 0.181 & 0.061 & 0.863 & 0.075 & 0.888 & 530.9 \\
\hline \multirow[t]{2}{*}{$\mathrm{CH}$} & $F$ & 0.212 & 0.044 & 1.614 & 0.098 & 0.914 & 2272.1 \\
\hline & $M$ & 0.305 & 0.025 & 1.378 & 0.036 & 0.949 & 1472.8 \\
\hline \multirow[t]{2}{*}{ TW } & $\mathrm{F}$ & 0.591 & 0.094 & 2.001 & 0.075 & 0.972 & 1716.8 \\
\hline & $M$ & 0.326 & 0.049 & 2.327 & 0.176 & 0.939 & 4191.5 \\
\hline
\end{tabular}


parameters described by Roper and Voss [20]: Cuttlebone Length (CL), Total Cuttlebone Length (CL1), Cuttlebone Height $(\mathrm{CH})$, Cuttlebone Width $(\mathrm{CW})$, Fragmocone Length (FL), Fragmocone Width (FW), Internal Cuttlebone Width (ICW), and External Cuttlebone Width (ECW) (Fig. 1). All length measurements were taken to the nearest millimetre $(0.001)$, and the weights were taken to the nearest centigram (0.01). For each specimen, sex was determined macroscopically, and the maturity stage was assigned based on the scale described by Nigmatullin [21]. Total cuttlebone length (CL1) was not taken in individuals with totally or partially fractured spines due to damages during trawling or handling on board.

To observe differences between the parts of the cuttlebone and the DML, a regression analysis was performed using the linear regression model (Table 1). These functions were performed individually for males (247 individuals) and females (74 individuals). Analysis of covariance (ANCOVA) was performed to detect significant differences between male and female cuttlebones. The first test determined whether the regression slopes for each size class are statistically homogeneous. If the slopes are homogeneous, the second test was performed to verify whether there were differences between sexes in each size class. The mean values of the dependent variables (cuttlebone measurements) for each size class predict differences between sexes. Moreover, the gonadosomatic index $(\mathrm{GSI}=\mathrm{GW} / \mathrm{TW} \times 100)$ of the individuals was calculated and plotted against cuttlebone measures to determine eventual differences between sexes. All statistical analyses were performed using $\mathrm{R}$ ( $\mathrm{v}$ 3.4.2) IBM-SPSS Statistics@ package.

\section{Results}

DML ranged between 63 and $133 \mathrm{~mm}$ in males and $67-110 \mathrm{~mm}$ in females, whereas TW was $35.5-192.9 \mathrm{~g}$ in males and 37.3-103.5 $\mathrm{g}$ in females. The morphometric relationships established through regression analyses between DML and cuttlebone measurements in males and females are compiled in Table I. The relationship DML-CL1 displayed the lowest Pearson correlation coefficient ( $r$ ) for both sexes, which could due to the low number of specimens without broken spines.

ANCOVA revealed that FW $(\mathrm{F}=124.417, p<0.0001)$, $\mathrm{CW}(\mathrm{F}=449.185, p<0.0001)$, and ECW $(\mathrm{F}=148.228$, $p<0.0001)$ were the morphometric measurements with statistically significant differences between sexes. These differences indicated that cuttlebone width, fragmocone width and external width are proportionally larger in females compared with males for a given length class (Figs. 2, 3a-c). Female cuttlebones also presented greater

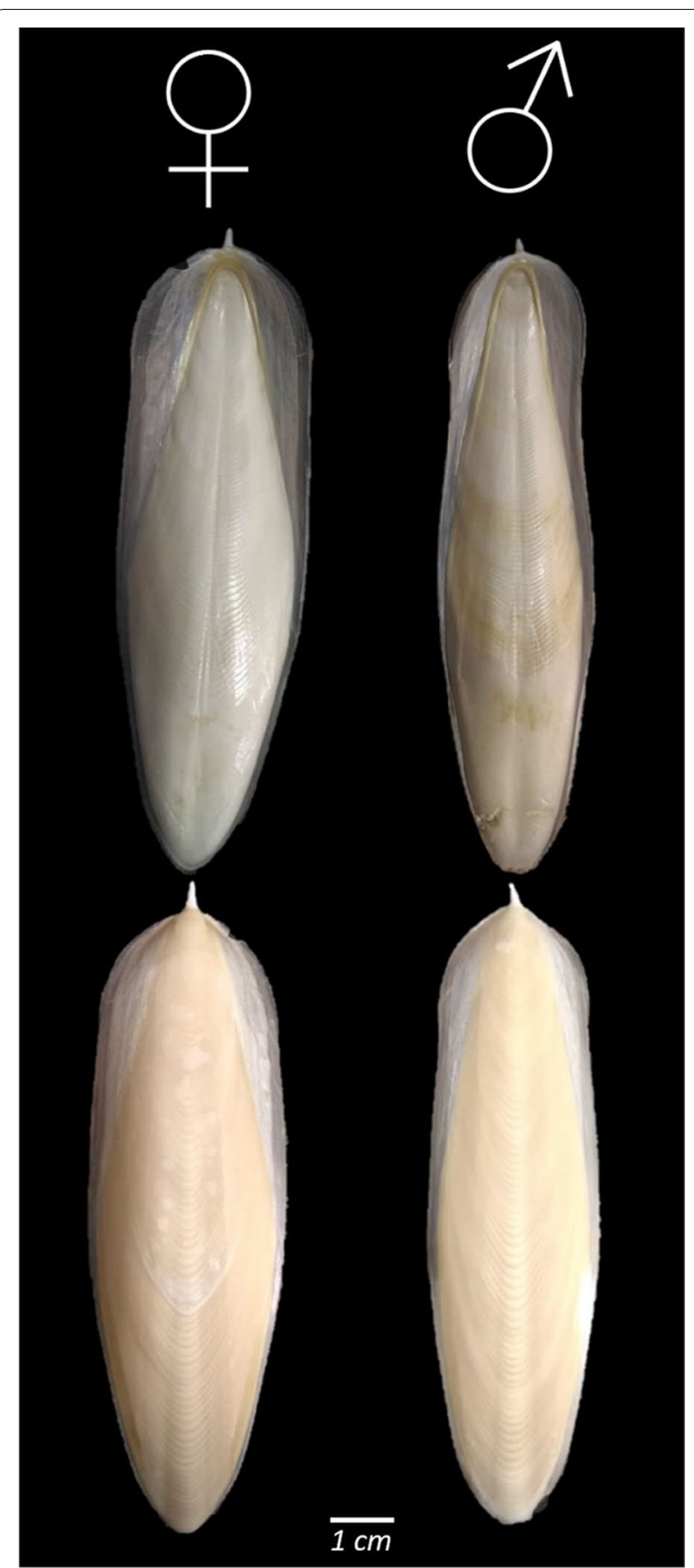

Fig. 2 Dorsal and ventral views of the cuttlebone of a mature female $(\mathrm{DML}=96.0 \mathrm{~mm})$ and male $(\mathrm{DML}=95.3 \mathrm{~mm})$

weights than male cuttlebones for the same length class (Fig. 3d).

All individuals were mature and showed a high development of the gonads, being ready to spawn. Significant differences were recorded between the GSI of males and females in relation to FW, CW and ECW (Fig. 4b-d). 

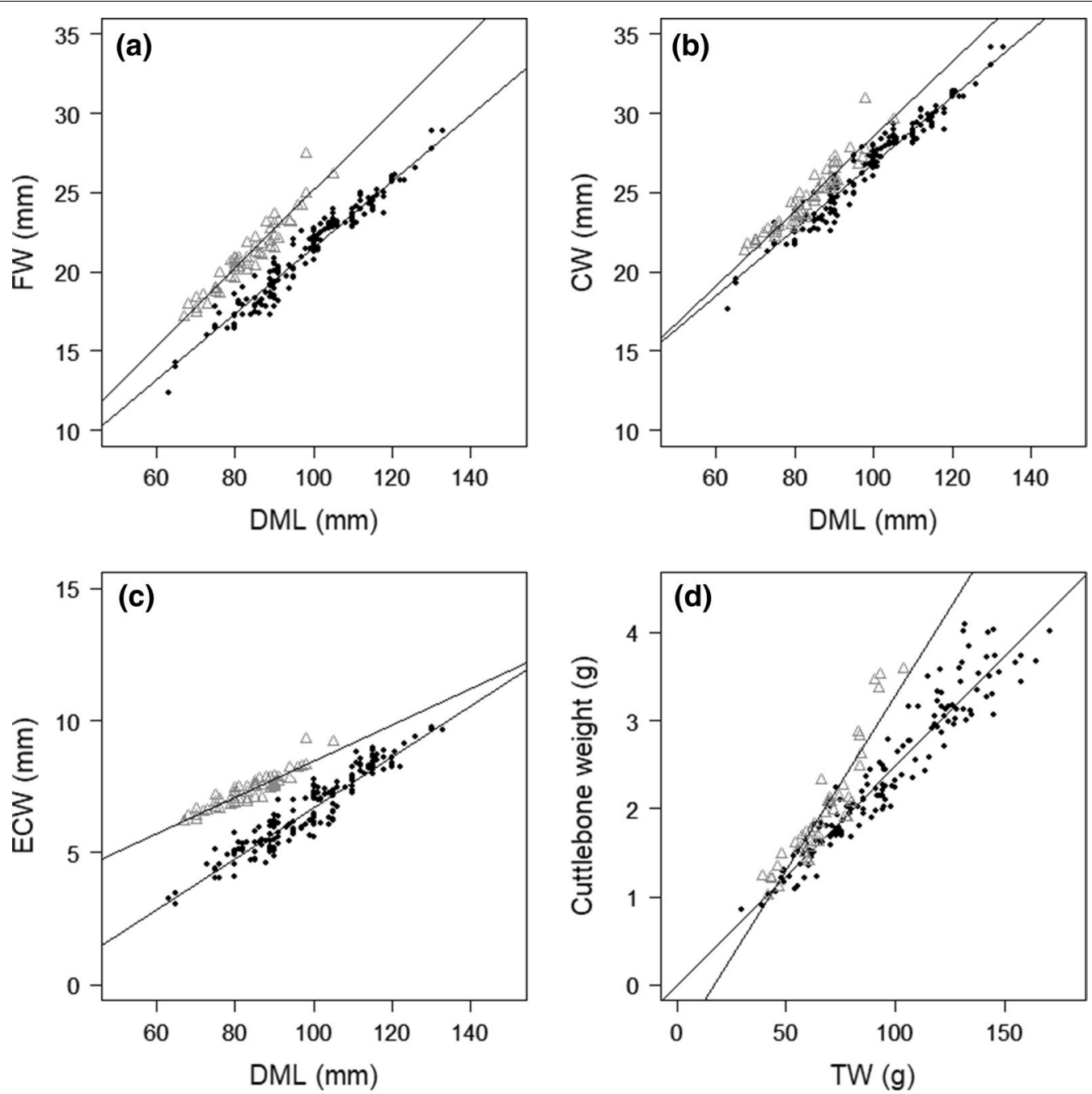

Fig. 3 Morphometric relationships between Dorsal Mantle Length (DML) and a Fragmocone Width (FW), b Cuttlebone Width (CW), c External Cuttlebone Width (ECW) and between $\mathbf{d}$ Total wet Weight (TW) and Cuttlebone weight (CW) for males (black dots) and females (empty triangles) of Sepia bertheloti

\section{Discussion}

External sexual dimorphism of Sepia bertheloti was mainly based on the fact that males present median arm suckers with greater diameter than marginal suckers and hectocotylus in the left ventral arm. Apart from sexual structures, females internally show the buccal membrane extending ventrally with two spermathecae [12]. However, minimal attention has been paid to cuttlebone as a potential element to differentiate males from females. This study showed that female cuttlebones are significantly wider probably due to the need for a bigger volume of the paleal cavity to increase the capacity to accommodate the gonads. Jereb and Roper [12] remarked that the mantle is relatively wider in females than in males.
Sepia bertheloti males are larger than females [12], which is also noted in S. latimanus [9, 22], S. koilados, S. rhoda, and S. subplana. However, in most cuttlefish species (i.e., S. acuminata, S. australis, S. bidhaia, S. braggi, S. elegans, S. filibranchia, S. grahami, S. hedley, S. latimanus, S. limata, S. mestus, S. orbignyana, S. plana, S. senta, S. smithi, S. sulcata, Sepiella inermis, and S. weberi) females growth larger than males [12]. Regarding S. latimanus, Dan et al. [22] observed that there were no morphometric differences in the growth pattern of both sexes during the initial life stages, but males become larger than females after 1 year of age. Males and females of $S$. bertheloti caught more northwards than the distributional range given by Jereb and Roper [12] presented a maximum size of 133 and $100 \mathrm{~mm}$ DML, respectively, 

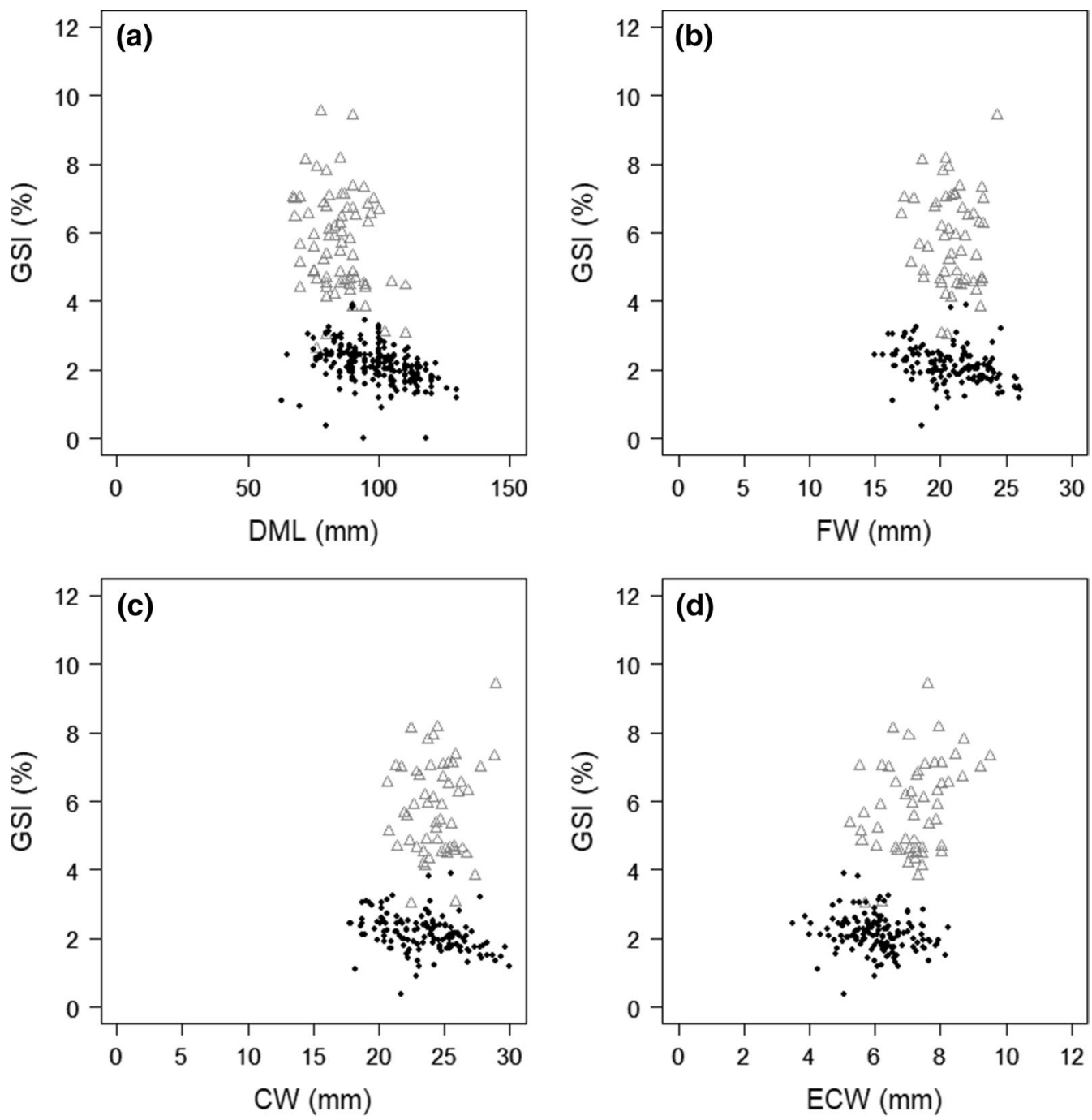

Fig. 4 Relationships between Gonadosomatic Index (GSI) and a Dorsal Mantle Length (DML), b Cuttlebone width (CW), c Fragmocone width (FW) and $\mathbf{d}$ External Cuttlebone Width (ECW) for males (black dots) and females (empty triangles) of Sepia bertheloti

which is clearly smaller than the maximum sizes reported by Jereb and Roper [12] for the Eastern Atlantic (175 and $134 \mathrm{~mm}$ DML, respectively). However, females were usually wider, and this aspect could be associated with the wider morphometric structure of their cuttlebone for a given mantle length.

This differentiation of the cuttlebone between sexes with females with a broader cuttlebone has also been described in other cuttlefish species, such as $S$. officinalis [4], S. prabahari, S. weberi and Sepiella ornata [12]. Therefore, although $S$. bertheloti males and females cannot be differentiated macroscopically (except for the presence of a hectocotylus), they show sexual differences in the morphometric structure of the cuttlebone.
The present results are comparable to those obtained by Almonacid-Rioseco et al. [4] for S. officinalis, which also showed a differentiation between sexes for the same measurements of the cuttlebone (FW, CW, ECW). These results reveal that sexes have a relatively different growth pattern. Specifically, males exhibit faster growth in length to reach larger sizes, while females exhibit greater growth in the cuttlebone width in preparation for reproduction (Fig. 3a-c). Vasconcelos et al. [23] also describe this sexual dimorphism for $S$. officinalis in the Algarve coast (southern Portugal). On the other hand, the gonadosomatic index allowed comparison of gonadal development with the cuttlebone measurements that presented differences between sexes, revealing that the faster growth in width of female cuttlebone 
is related to an increase in gonadal mass. Accordingly, this relationship can be interpreted as an adaptation of the female body to the gonadal development, which always exhibits increased occupation compared with the male gonad. In this sense, Akyol et al. [24] reported that the total number of oocytes produced by $S$. officinalis varied from 49 to 828 with an average of $261 \pm 27$ per female, whereas Laptikhovsky et al. [25] reported a range of large yolk oocytes between 130 and 839 . This body adaptation hypothesis was previously proposed by Hewitt and Stait [26] and Sainz [27], who mentioned that these changes in S. officinalis were due to phylogenetic features where females adapted to their reproductive stage by developing a wider cuttlebone than males. The volume of oocytes could justify a larger capacity of the female paleal cavity and therefore the adaptation of female cuttlebone to provide the required support and space.

Due to the lack of immature individuals, we are not able to determine whether the differentiation between sexes based on cuttlebone morphometrics is only possible when analysing ripe individuals prior to spawning (i.e., when the cuttlebone morphology adapts to lodge the voluminous gonad), which would decrease the usefulness of this "tool" for gender identification in juveniles stages.

\section{Acknowledgements}

Not applicable.

\section{Authors' contributions}

AG-M performed data collection and analysis and interpretation of the results. LC-M performed data collection and analysis. DJ-A performed data collection and interpretation of results. JJC-H performed data analysis and interpretation of the results. The manuscript was written and substantially revised by all the authors, who also approved the version submitted to the journal. All authors read and approved the final manuscript.

\section{Funding}

This article has not been funding by any institution.

\section{Availability of data and materials}

The datasets generated and analysed during the current study are not publicly available because data are being used for another research, but are available from the corresponding author on reasonable request.

\section{Ethics approval and consent to participate}

The scientific study was conducted with animals from commercial fishing without any treatment of live animals.

\section{Consent for publication}

Not applicable.

\section{Competing interests}

The authors declare that they have no competing interests.

Received: 7 February 2019 Accepted: 25 September 2019

Published online: 23 October 2019

\section{References}

1. Hoyle WE. Reports on the Cephalopoda collected by H.M.S. Challenger during the years 1873-1876. Report of the scientific results of the voyage of H.M.S. Challenger, 1873-1876. Zoology. 1886;16:1-245.

2. Neige P. Morphometrics of hard structures in cuttlefish. Vie et Milieu. 2006;56(2):121-8.

3. Guerra A, Pérez-Losada M, Rocha F, Sanjuan A. Species differentiation of Sepia officinalis and Sepia hierredda (Cephalopoda: Sepiidae) based on morphological and allozyme analyses. J Mar Biol Assoc UK. 2001;81:271-81.

4. Almonacid-Rioseco E, Hernández-García V, Solari AP, Del Pino ÁS, Castro JJ. Sex identification and biomass reconstruction from the cuttlebone of Sepia officinalis. Marine Biodiver Records. 2009;2:1-4.

5. Guerra A. Mollusca, cephalopoda. In: Ramos MA, editor. Fauna Ibérica, vol. 1. Madrid: Museo Nacional de Ciencias Naturales, CSIC; 1992.

6. Checa AG, Cartwright JH, Sánchez-Almazo I, Andrade JP, Ruiz-Raya F. The cuttlefish Sepia officinalis (Sepiidae, Cephalopoda) constructs cuttlebone from a liquid-crystal precursor. Sci Rep. 2015:5:11513.

7. Hare PE, Abelson PH. Amino acid composition of some calcified proteins, vol. 64. Washington: Carnegie Inst, Washington Year Book; 1965. p. 223-32.

8. Richard A. The part placed by temperature in the rhythm of formation of markings on the shell of cuttlefish (Sepia officinalis L.) (Cephalopoda, Mollusca). Experientia. 1969;25:1051-2.

9. Bettencourt V, Guerra A. Age studies based on daily growth increments in statoliths and growth lamellae in cuttlebone of culture Sepia officinalis. Mar Biol. 2001;139(2):327-34.

10. Chung MT, Wang CH. Age validation of the growth lamellae in the cuttlebone from cultured Sepia pharaonis at different stages. J Exp Mar Biol Ecol. 2013;447:132-7.

11. Jouffre $D$, Inejih CA. Assessing the impact of fisheries on demersal fish assemblages of the Mauritanian continental shelf, 1987-1999, using dominance curves. ICES J Mar Sci. 2005;62(3):380-3.

12. Jereb P, Roper CFE (eds). Cephalopods of the world. An annotated and illustrated catalogue of cephalopods species known to date, vol. 1. Chambered nautiluses and sepioids (Nautilidae, Sepiidae, Sepiolidae, Sepiadariidae, Idiosepiidae and Sepirulidae). FAO Species Catalogue for Fishery Purposes 2005, p 262.

13. Delgado de Molina-Acevedo A, Santana-Fernández JC, Ariz-Telleria J, Goni-Beltran de Garizurieta R. Biological-fishing parameters of some species of the Sepiidae Keferstein, 1866, collected during the IBNSINA Survey (1980-1982). Boletin del Instituto Español de Oceanografia. 1993;9(1):41-56.

14. Monzón-Argüello C, Cardona L, Calabuig P, Camacho M, Crespo-Picazo JL, García-Párraga D, Varo-Cruz N. Supplemental feeding and other anthropogenic threats to green turtles (Chelonia mydas) in the Canary Islands. Sci Total Environ. 2018;621:1000-11.

15. Balguerías-Guerra E, Hernández-González CL, Fernández-Nuñez M, Perales-Raya C. Analysis of discards produced by the Spanish cephalopod-fishing fleet at the Sahara Bank. Boletin del Instituto Espanol de Oceanografia. 1993;9(1):75-88.

16. Rocha F, Fernández-Gago R, Ramil F, Ramos A. Cephalopods in mauritanian waters. In: Deep-sea ecosystems off mauritania. 2017. p. 393-417.

17. Ama-Abasi D, Akpan I. Elemental concentration and size relationship in African cuttlefish Sepia bertheloti, from the coastal waters of Qua Iboe River, Nigeria. In: 22nd Annual Conference of the Fisheries Society of Nigeria (FISON), 12-16 Nov 2007, Kebbi, Nigeria; 2008. p. 245-9.

18. Almonacid-Rioseco El. Contribución a la ecología de Sepia officinalis (Cephalopoda: Sepiidae) en Gran Canaria. Mem. Tesis Doctoral, Universidad de las Palmas de Gran Canaria, Spain. 2006.

19. Nesis KN. Cephalopods of the world: squid, cuttlefishes, octopuses, and allies. In: Translated from Russian by BS Levitov. 1987.

20. Roper CF, Voss GL. Guidelines for taxonomic descriptions of cephalopod species. Memoirs Natl Museum Victoria. 1983:44:49-63.

21. Nigmatullin CM. Las especies de calamar más abundantes del Atlántico Sudoeste y sinopsis sobre la ecología del calamar (Illex argentinus). Frente Marítimo. 1989:5:71-81. 
22. Dan S, Hamasaki K, Yamashita T, Oka M, Kitada S. Age-based life cycle traits of the broadclub cuttlefish Sepia latimanus confirmed through release-recapture experiments. Aquat Biol. 2012;17:181-95.

23. Vasconcelos P, Pereira F, Carvalho AN, Gaspar MB. Weight-length relationships and relative growth of the cuttlefish (Sepia officinalis): causes and effects of hypoallometry. Thalassas Int J Mar Sci. 2018;34(2):323-31.

24. Akyol O, Tellibayraktat B, Ceyhan T. Preliminary results on the cuttlefish Sepia officinalis, reproduction in Izmir Bay (Aegean Sea). J Fisher Sci. 2011:5(2):122-30.

25. Laptikhovsky V, Salman A, Oensoy B, Katagan T. Fecundity of the common cuttlefish, Sepia officinalis (Cephalopoda, Sepiidae): a new look at an old problem. Scientia Marina. 2003;67(3):279-84.
26. Hewitt RA, Stait B. Seasonal variation in septal spacing of Sepia officinalis and some Ordovician actinocerid nautiloids. Lethaia. 1988;11:383-94.

27. Sainz J. Cuttlebone development in Sepia officinalis. 1990. Pac Sci. 1990;44:194-5

\section{Publisher's Note}

Springer Nature remains neutral with regard to jurisdictional claims in published maps and institutional affiliations.
Ready to submit your research? Choose BMC and benefit from:

- fast, convenient online submission

- thorough peer review by experienced researchers in your field

- rapid publication on acceptance

- support for research data, including large and complex data types

- gold Open Access which fosters wider collaboration and increased citations

- maximum visibility for your research: over $100 \mathrm{M}$ website views per year

At BMC, research is always in progress.

Learn more biomedcentral.com/submissions 